Si mple and sel ective determ nation of ar senite and ar senate by el ect rospr ay i oni zat i on mass spect r omet ry

\begin{tabular}{|l|l|}
\hline 著者 & M nakat a Kayoko, Suzuki Nasako, Suzuki Osamu \\
\hline $\begin{array}{l}\text { j our nal or } \\
\text { publ i cat i on ti t l e }\end{array}$ & Anal yt i ca Chi mi ca Act a \\
\hline vol une & 631 \\
\hline number & 1 \\
\hline page r ange & $87-90$ \\
\hline year & 2009- 01-05 \\
\hline URL & ht t p: //hdl . handl e. net /10271/1797 \\
\hline
\end{tabular}




\title{
Simple and selective determination of arsenite and arsenate by electrospray ionization mass spectrometry
}

\author{
Kayoko Minakata ${ }^{a} *$ Masako Suzuki $^{\mathrm{b}}$ and Osamu Suzuki ${ }^{\mathrm{a}}$ \\ ${ }^{a}$ Department of Legal Medicine, ${ }^{b}$ Research Equipment Center, Hamamatsu University \\ School of Medicine, 1-20-1 Handayama, Hamamatsu 431-3192, Japan \\ *Corresponding author: (e-mail) kminakat@hama-med.ac.jp
}

\section{ABSTRACT}

Arsenic pollution of public water supplies has been reported in various regions of the world. Recently, some cancer patients are treated with arsenite (As ${ }^{\mathrm{III}}$ ); most Japanese people consume seafoods containing large amounts of negligibly toxic arsenic compounds. Some of these arsenic species are metabolized, but some remain intact. For the determination of toxic As ${ }^{\mathrm{III}}$, a simple, rapid and sensitive method has been developed using electrospray ionization mass spectrometry (ESI-MS). $\quad \mathrm{As}^{\mathrm{III}}$ was reacted with a chelating agent, pyrrolidinedithiocarbamate $\left(\mathrm{PDC}, \mathrm{C}_{4} \mathrm{H}_{8} \mathrm{NCSS}^{-}\right)$and tripyrrolidinedithiocarbamate-arsine, $\mathrm{As}(\mathrm{PDC})_{3}$, extracted with methyl isobutyl ketone (MIBK). A $1-\mu \mathrm{L}$ aliquot of MIBK layer was directly injected into ESI-MS instrument without chromatographic separation, and was detected within 1 min. Arsenate $\left(\mathrm{As}^{\mathrm{V}}\right)$ was reduced to $\mathrm{As}{ }^{\mathrm{III}}$ with thiosulfate, and then the total inorganic As was quantified as As ${ }^{\text {III }}$ This method was validated for the analysis of urine samples. The limit of detection of As was $0.22 \mu \mathrm{gL}^{-1}$ using $10 \mu \mathrm{L}$ of sample solution, and it is far 
below the permissible limit of As in drinking water, $10 \mu \mathrm{gL}^{-1}$, recommended by the WHO. Results were obtained in $<10$ min with a linear calibration range of $1-100$ $\mu \mathrm{gL}^{-1}$. Several organic arsenic compounds in urine did not interfere with As ${ }^{\mathrm{III}}$ detection, and the inorganic As in the reference materials SRM 2670a and 1643e were quantified after the reduction of $\mathrm{As}^{\mathrm{V}}$ to $\mathrm{As}{ }^{\mathrm{III}}$.

Key words: Arsenite, Arsenate, Mass spectrometry, Electrospray ionization, Pyrrolidinedithiocarbamate

\section{Intoduction}

There is considerable interest in establishing methods for determining the concentration of individual species of arsenic (As) because toxicity depends on its molecular form. Toxicity increases in the approximate order: metallic As $<$ organoarsenic compounds $<\operatorname{arsenate}\left(\mathrm{As}^{\mathrm{V}}\right)<\operatorname{arsenite}\left(\mathrm{As}^{\mathrm{III}}\right)<\operatorname{arsine}\left(\mathrm{AsH}_{3}\right)$, although some methylated $\mathrm{As}^{\mathrm{III}}$ compounds are reported to be more toxic than $\mathrm{As}{ }^{\mathrm{III}}$ [1]. Many analytical techniques have been employed for various samples to separate and quantify these As species: atomic absorption spectrometry [2], gas-liquid chromatography [3], liquid chromatography (LC)-hydride generation-atomic fluorescence spectrometry [4,5] and LC-inductively coupled plasma (ICP) mass spectrometry (MS) [1,6-11]. Although these techniques (particularly LC-ICP-MS) offer the advantages of high selectivity in determining its atomic mass $m / z=75$ and high sensitivity with a limit of detection (LOD) of $0.14-0.33 \mu \mathrm{gL}^{-1}[1,6-8]$, the identification of chemical species is based entirely on agreement of the chromatographic retention time with that of the 
reference compound. In some chromatographic separations, highly toxic As ${ }^{\mathrm{III}}$ elutes with negligibly toxic arsenobetaine (AsB; derived from seafoods) [10] or monomethylarsonic acid (MMA; metabolite of $\mathrm{As}^{\mathrm{III}}$ excreted into urine) $[1,10]$. Detection of ${ }^{75} \mathrm{As}, \mathrm{m} / \mathrm{z}=75$ is readily interfered with by isobars such as $\mathrm{FeOH}[11]$ and $\mathrm{ArCl}$ resulting from the combination of $\mathrm{Ar}$ (from plasma gas) and $\mathrm{Cl}$ (from sample solution) $[1,11]$.

Electrospray ionization (ESI)-MS provides a unique opportunity for the analysis of molecular forms of species [6,12-15], and the LODs for several organoarsenic compounds on LC-ESI-MS/MS, $1 \mu \mathrm{g}(\mathrm{kg})^{-1}$ [15], is comparable to that on LC-ICP-MS [1,6-8]. Inorganic $\mathrm{As}^{\mathrm{III}}$ and $\mathrm{As}^{\mathrm{V}}$, however, could not be quantified on ESI-MS (/MS) sensitively, and only qualitative data have been provided in reports $[6,12-15]$. Instruments of ICP-MS and ESI-MS (/MS) were therefore required for the selective and sensitive quantification of inorganic and organic As species. We intended to quantify inorganic As sensitively by ESI-MS. Inorganic As ${ }^{\mathrm{III}}$ was reacted with a chelating agent, pyrrolidinedithiocarbamate ( $\left.\mathrm{PDC} ; \mathrm{C}_{4} \mathrm{H}_{8} \mathrm{NCSS}^{-}\right)$, and tripyrrolidinedithiocarbamate-arsine, $\mathrm{As}(\mathrm{PDC})_{3}$, was extracted with methyl isobutyl ketone (MIBK) [16,17]. An aliquot $(1 \mu \mathrm{L})$ of the MIBK layer was directly injected into the ESI-MS instrument without chromatographic separation, although chromatographic separation was adopted in other studies [1,3-11,13]. $\quad \mathrm{As}^{\mathrm{V}}$ does not react with PDC [16,17], so $\mathrm{As}^{\mathrm{V}}$ was reduced to $\mathrm{As}{ }^{\mathrm{III}}$ with $0.01 \mathrm{M} \mathrm{Na}_{2} \mathrm{~S}_{2} \mathrm{O}_{3}$ in $0.1 \mathrm{M} \mathrm{HCl}$ for 1-5 min and the total inorganic As quantified as As ${ }^{\mathrm{III}}$. The present method could afford a sensitive determination of As. LOD was $0.22 \mu \mathrm{gL}^{-1}$ with a quantification range of $1-100 \mu \mathrm{gL}^{-1}$ using $10 \mu \mathrm{L}$ of sample solution. LOD was far below the 
permissible limit of As in drinking water, $10 \mu \mathrm{gL}^{-1}$, recommended by the WHO [2].

\section{Materials and methods}

Atomic absorption standard solutions (AASS) of As ${ }^{\mathrm{III}}$ and other 20 metals, atomic absorption grade of MIBK, PDC, sodium diethyldithiocarbamate (DDC), diethylammonium DDC and ammonium DDC, and analytical grade of $\mathrm{NaAsO}_{2}\left(\mathrm{As}^{\mathrm{III}}\right)$, $\mathrm{Na}_{2} \mathrm{HAsO}_{4} \cdot 7 \mathrm{H}_{2} \mathrm{O}\left(\mathrm{As}^{\mathrm{V}}\right)$, sodium disulfite $\left(\mathrm{Na}_{2} \mathrm{~S}_{2} \mathrm{O}_{5}\right)$, sodium thiosulfate $\left(\mathrm{Na}_{2} \mathrm{~S}_{2} \mathrm{O}_{3}\right)$, sodium hydrosulfite $\left(\mathrm{Na}_{2} \mathrm{~S}_{2} \mathrm{O}_{4}\right)$, dimethylarsinic acid (DMA), AsB, arsenocholine (AsC) bromide and other reagents were obtained from Wako Pure Chemicals, Osaka, Japan. Analytical-grade MMA was obtained from Tri Chemical Laboratories Incorporated, Yamanashi, Japan. Standard reference materials (SRM 2670a and 1643 e) were purchased from the National Institute of Standards and Technology, Gaithersburg, MD, USA. Pure water having a specific resistance of $18 \mathrm{M} \Omega \mathrm{cm}$ was used. AASS of As ${ }^{\mathrm{III}}$ at $1 \mathrm{gL}^{-1}$ was the stock solution. Other stock solutions at $1 \mathrm{gL}^{-1}$ As were prepared by dissolving $\mathrm{NaAsO}_{2}\left(\mathrm{As}^{\mathrm{III}}\right)$ and $\mathrm{Na}_{2} \mathrm{HAsO}_{4} \cdot 7 \mathrm{H}_{2} \mathrm{O}\left(\mathrm{As}^{\mathrm{V}}\right)$ in water, and used for one week. Calibration standard solutions and quality control solutions were freshly prepared before use by spiking stock solutions at As concentrations of $0,1,10$ and $100 \mu \mathrm{g} \mathrm{L}^{-1}$ to water and urine that contained $\mathrm{Na}_{2} \mathrm{~S}_{2} \mathrm{O}_{5}$ at $0.003 \mathrm{M}$ in the case of $\mathrm{As}{ }^{\mathrm{III}}$, and to water and urine in the case of $\mathrm{As}^{\mathrm{V}}$, respectively. $\quad \mathrm{pH}$ of the sample and standard solutions was adjusted to $3-5$ using $1 \mathrm{M} \mathrm{HCl}$ solution and $1 \mathrm{M} \mathrm{NaOH}$ solution using $\mathrm{pH}$ test paper in assay for $\mathrm{As}^{\mathrm{III}}$ or $\mathrm{As}{ }^{\mathrm{V}}$, if necessary.

$\mathrm{As}^{\mathrm{III}}$ was assayed as follows. To $10 \mu \mathrm{L}$ of sample or standard solution in a polypropylene tube with cap (Eppendorf AG, Germany), $1 \mu \mathrm{L}$ of $0.03 \mathrm{M} \mathrm{Na}_{2} \mathrm{~S}_{2} \mathrm{O}_{5}$ and 1 
$\mu \mathrm{L}$ of $0.1 \mathrm{M}$ PDC were added. After $30 \mathrm{~s}, 10 \mu \mathrm{L}$ of MIBK was added, mixed with a vortex mixer for $30 \mathrm{~s}$, and centrifuged at $5000 \times \mathrm{g}$ for $30 \mathrm{~s}$. The MIBK layer was used for the detection of $\mathrm{As}^{\mathrm{III}}[16,17]$.

$\mathrm{As}^{\mathrm{V}}$ was assayed as follows. To $10 \mu \mathrm{L}$ of sample or standard solution, $1 \mu \mathrm{L}$ of 1 $\mathrm{M} \mathrm{HCl}$ solution and $1 \mu \mathrm{L}$ of $0.1 \mathrm{M} \mathrm{Na}_{2} \mathrm{~S}_{2} \mathrm{O}_{3}$ solution were added. The reaction was allowed to proceed for $1-5 \mathrm{~min}$ at room temperature to reduce $\mathrm{As}^{\mathrm{V}}$ to $\mathrm{As}{ }^{\mathrm{III}}$ completely. $\mathrm{pH}$ of the solution was adjusted to $3-5$ using $1 \mathrm{M} \mathrm{NaOH}$ solution, and $1 \mu \mathrm{L}$ of $0.1 \mathrm{M}$ PDC added. After $30 \mathrm{~s}, 10 \mu \mathrm{L}$ of MIBK was added, mixed with a vortex mixer for 30 $\mathrm{s}$, and centrifuged at $5000 \times \mathrm{g}$ for $30 \mathrm{~s} . \quad \mathrm{As}^{\mathrm{III}}$ in the sample remained unchanged, and total $\mathrm{As}^{\mathrm{V}}$ and $\mathrm{As}^{\mathrm{III}}$ were determined as $\mathrm{As}^{\mathrm{III}}$. The amount of $\mathrm{As}^{\mathrm{V}}$ was calculated by subtracting the amount of $\mathrm{As}^{\mathrm{III}}$ determined initially from the total amount of $\mathrm{As}^{\mathrm{v}}$ and $\mathrm{As}^{\mathrm{III}}$ determined subsequently.

ESI-MS was done on a TSQ 7000 LC-quadrupole mass spectrometer (Thermo Quest, Japan) in positive ion mode. One microliter of the MIBK layer was injected manually in direct mode. The characteristic spectrum appeared $30 \mathrm{~s}$ after sample injection, and a sample could be injected every $60 \mathrm{~s}$. Methanol was used as a mobile phase at $200 \mu \mathrm{Lmin}^{-1}$ and the capillary temperature was set at $250^{\circ} \mathrm{C}$. The electrospray voltage was set at $4.5 \mathrm{kV}$ and multiplier voltage at $1.3 \mathrm{kV}$. Nitrogen was used as a sheath gas (469 $\mathrm{kPa})$ and as an auxiliary gas (8 units). $\quad$ MS data were collected at $m / z$ 340-390. The quantification in ESI-MS was done by the integration of the peak area of $\mathrm{As}(\mathrm{PDC})_{2}{ }^{+}$at $\mathrm{m} / \mathrm{z} 367 \pm 0.5$ in selected ion monitoring using a calibration curve comprising spiked matrix samples at different concentrations. 


\section{Results and discussion}

\subsection{Preservation of valence states of $A s^{\mathrm{III}}$ and $A s^{\mathrm{V}}$}

We found that $\mathrm{As}^{\mathrm{III}}$ at $<10 \mu \mathrm{gL}^{-1}$ in pure aqueous solution was undetectable when it reacted with PDC and was extracted with MIBK. This may be due to non-optimized $\mathrm{pH}$ of the solution, as well as the oxidation of $\mathrm{As}^{\mathrm{III}}$ under our assay treatment, which involved violent mixing using a vortex mixer. $\quad \mathrm{Na}_{2} \mathrm{~S}_{2} \mathrm{O}_{5}, \mathrm{HCl}$ [5], $\mathrm{HNO}_{3}$ and EDTA disodium salt (2Na) [5] were tested to preserve the valence states of $\mathrm{As}^{\mathrm{III}}$ and $\mathrm{As}^{\mathrm{V}}$ and to sensitively detect only $\mathrm{As}^{\mathrm{III}}$. The peak area derived from $\mathrm{As}^{\mathrm{III}}$ at $100 \mu \mathrm{gL}^{-1}$ in $0.003 \mathrm{M} \mathrm{Na}_{2} \mathrm{~S}_{2} \mathrm{O}_{5}$ solution was taken as $100 \%$, and the relative percentage values of the peak area derived from the other solutions were examined. Concentration of As ${ }^{\text {III }}$ or $\mathrm{As}^{\mathrm{V}}$ was 0 in blank solution or $100 \mu \mathrm{gL}^{-1}$ in test solution. The As-PDC complex was produced most efficiently at $\mathrm{pH} 3-5$ in this study, although the suitable $\mathrm{pH}$ range reported previously was $1-6.8[17] . \quad \mathrm{Na}_{2} \mathrm{~S}_{2} \mathrm{O}_{5}$ was chosen because it is a moderate reducing agent and its $\mathrm{pH}$ value is about 4 at $0.001-0.1 \mathrm{M}$ solution. $\quad \mathrm{As}^{\mathrm{III}}$ at 100 $\mu \mathrm{gL}^{-1}$ in $0.001-0.02 \mathrm{M} \mathrm{Na}_{2} \mathrm{~S}_{2} \mathrm{O}_{5}$ solutions showed the peak of $\mathrm{As}(\mathrm{PDC})_{2}{ }^{+}$ corresponding to $100 \%$, whereas $\mathrm{As}^{\mathrm{V}}$ at $100 \mu \mathrm{gL}^{-1}$ did not show the peak of $\mathrm{As}(\mathrm{PDC})_{2}{ }^{+}$, even in $0.1 \mathrm{M} \mathrm{Na}_{2} \mathrm{~S}_{2} \mathrm{O}_{5}$ solution. The peak area of the blank solution $(0.001-0.02 \mathrm{M}$ $\mathrm{Na}_{2} \mathrm{~S}_{2} \mathrm{O}_{5}$ solutions) was $<1 \%$ of that of $\mathrm{As}^{\mathrm{III}}$ at $100 \mu \mathrm{gL}^{-1}$. Therefore, $0.001-0.02 \mathrm{M}$ $\mathrm{Na}_{2} \mathrm{~S}_{2} \mathrm{O}_{5}$ solutions can be used for the selective determination of $\mathrm{As}^{\mathrm{III}}$ without interference from $\mathrm{As}^{\mathrm{V}}$, although 0.01 $\mathrm{M} \mathrm{HCl}$ solution and 0.01 M EDTA 2Na solution gave satisfactory results in other studies on $\mathrm{As}^{\mathrm{III}}[5]$.

We confirmed that spiked As ${ }^{\mathrm{III}}$ at $1-100 \mu \mathrm{gL}^{-1}$ into urine could be detected completely when urine contained $\mathrm{Na}_{2} \mathrm{~S}_{2} \mathrm{O}_{5}$ at $0.001-0.02 \mathrm{M}$. 


\subsection{Suitable chelating agents and extracting solvents}

Four chelating agents, sodium DDC, diethylammonium DDC, ammonium DDC and ammonium PDC, were compared. Three types of DDC compounds gave almost identical amounts of As-DDC complex. The amount of As-DDC complex produced from any of the three DDC compounds was only one-tenth that of the As-PDC complex produced from ammonium PDC: ammonium PDC was chosen as the chelating agent.

MIBK was chosen as the extraction solvent of the As-PDC complex. Firstly, the peaks of blank extracted with MIBK, isoamylalcohol, octanol and cyclohexanol corresponded to approximately 45,80, 120 and 780\%, respectively, of the peak of $1 \mathrm{pg}$ As ${ }^{\text {III }}$ extracted with MIBK. Secondly, the peak of 100 pg As ${ }^{\text {III }}$ extracted with MIBK was highest among the peaks of $100 \mathrm{pg} \mathrm{As}{ }^{\mathrm{III}}$ extracted with these four solvents.

\subsection{Reduction of $A s^{\mathrm{V}}$ to $A s^{\mathrm{III}}$}

Under the present treatments for the assay of $\mathrm{As}^{\mathrm{III}}, \mathrm{As}^{\mathrm{V}}$ did not react with PDC $[15,16]$, so a reduction step must be preceded to detect $\mathrm{As}^{\mathrm{V}} . \quad \mathrm{Na}_{2} \mathrm{SO}_{3}, \mathrm{NaHSO}_{3}, \mathrm{Na}_{2} \mathrm{~S}_{2} \mathrm{O}_{5}$, $\mathrm{Na}_{2} \mathrm{~S}_{2} \mathrm{O}_{3}$ and $\mathrm{Na}_{2} \mathrm{~S}_{2} \mathrm{O}_{4}$ were tested to reduce $\mathrm{As}^{\mathrm{V}}$ to $\mathrm{As}{ }^{\mathrm{III}}$. Of these, only $\geq 0.01 \mathrm{M}$ $\mathrm{Na}_{2} \mathrm{~S}_{2} \mathrm{O}_{4}$ solution ( $\mathrm{pH} 4$ ) could reduce $\mathrm{As}^{\mathrm{V}}$ to $\mathrm{As}{ }^{\mathrm{III}}$ completely after 5 min at $100^{\circ} \mathrm{C}$; the other four solutions, even at $0.05 \mathrm{M}$, could not. $\quad \mathrm{Na}_{2} \mathrm{~S}_{2} \mathrm{O}_{4}$ solution at $\geq 0.01 \mathrm{M}$ could not efficiently reduce $\mathrm{As}^{\mathrm{V}}$ to $\mathrm{As}^{\mathrm{III}}$ in urine, so reduction in $0.1 \mathrm{M} \mathrm{HCl} \mathrm{[17]} \mathrm{was} \mathrm{attempted}$ because $\mathrm{As}^{\mathrm{V}}$ tends to be $\mathrm{As}{ }^{\mathrm{III}}$ in acid solution [5,17]. We found that $0.01 \mathrm{M} \mathrm{Na}_{2} \mathrm{~S}_{2} \mathrm{O}_{3}$ in $0.1 \mathrm{M} \mathrm{HCl}$ solution and $0.01 \mathrm{M} \mathrm{Na}_{2} \mathrm{~S}_{2} \mathrm{O}_{4}$ in $0.1 \mathrm{M} \mathrm{HCl}$ solution could completely reduce $\mathrm{As}^{\mathrm{V}}$ to $\mathrm{As}{ }^{\mathrm{III}}$ in urine after $1-5 \mathrm{~min}$ at room temperature. Although this 
reduction treatment is sufficient for further detection based on atomic absorption spectrometry [17], $\mathrm{pH}$ of the solution should be adjusted to $3-5$ in our assay before the addition of the chelating agent (PDC). After these treatments, complete recovery was obtained in urine samples spiked with $\mathrm{As}^{\mathrm{V}}$ and $\mathrm{As}{ }^{\mathrm{III}}$ at $1-100 \mu \mathrm{gL}^{-1}$, respectively.

The As-PDC complex extracted with MIBK was reported to be stable for 2 months [17]. We observed that ninety percent of the complex remained after $24 \mathrm{~h}$ in the MIBK extract from aqueous solution and, after $3 \mathrm{~h}$ in the extract from urine, respectively, under room light at $25^{\circ} \mathrm{C}$.

\subsection{Interference}

PDC is known to form di- and tripyrrolidinedithiocarbamates of various transition metals. We confirmed that the signal of As at $\mathrm{m} / \mathrm{z} 367$ was not interfered with by $\mathrm{Ti}$, V, Cr, Mn, Fe, Co, Ni, Cu, Zn, Zr, Mo, Ru, Pd, Ag, Cd, W, Pt, Au, Tl and Pb at 10 $\mathrm{mgL}^{-1}$ under the present assay treatment for $\mathrm{As}^{\mathrm{III}}$ or $\mathrm{As}^{\mathrm{V}}$. The effects of organic As compounds such as MMA, DMA, AsB and $\mathrm{AsC}$ at $100 \mathrm{mgL}^{-1}$ as As were examined, but none were converted into the same As-PDC complex derived from As ${ }^{\mathrm{III}}$ under the present assay treatment for $\mathrm{As}^{\mathrm{III}}$ or $\mathrm{As}^{\mathrm{V}}$. Interference by salts such as $\mathrm{NaCl}, \mathrm{NaNO}_{3}$ and $\mathrm{Na}_{2} \mathrm{SO}_{4}$ at levels up to $0.3 \mathrm{M}$ solution and that by urea up to $10 \%$ solution, respectively, were not observed.

\subsection{Mass spectra}

Figure 1 (a) and (b) show the mass spectrum of $\mathrm{As}(\mathrm{PDC})_{2}{ }^{+}$derived from $200 \mathrm{pg}$ of As ${ }^{\mathrm{III}}$ 
in $0.003 \mathrm{M} \mathrm{Na}_{2} \mathrm{~S}_{2} \mathrm{O}_{5}$ solution, and that derived from10 pg of $\mathrm{As}^{\mathrm{III}}$ in urine containing $0.003 \mathrm{M} \mathrm{Na}_{2} \mathrm{~S}_{2} \mathrm{O}_{5}$, respectively. Although As is a mono-isotopic element, the $\mathrm{As}(\mathrm{PDC})_{2}{ }^{+}$ion shows several lines due to isotopes of $\mathrm{H} \mathrm{C}, \mathrm{N}, \mathrm{O}$ and $\mathrm{S}$; these patterns serve as the identification of the ion. The theoretical abundance ratio of lines at $\mathrm{m} / \mathrm{z}$ 367: 368: 369: 370: 371 calculated using the Isotopic Distribution Calculator of Applied Biosystems Japan Limited was 100.0: 15.2: 18.8: 2.6: 1.4 and the ratio was held down to that of $10 \mathrm{pg}$ As. That is, the ratio of $10 \mathrm{pg}$ As extracted from urine was 100.0: 16.4: 19.8: 3.9: 0.0 (Figure $1(\mathrm{~b})$ ), and the deviation of each value from the theoretical value was $<1.4$, where the value of signal observed at $m / z=367$ was taken to be 100 . The lines with higher intensity observed at m/z 346 - 352 in Figure 1 (b) were derived mainly from $\mathrm{Fe}(\mathrm{PDC})_{2}{ }^{+}$, and this figure indicated that common transition elements in urine did not interfere with the detection of $\mathrm{As}^{\mathrm{III}}$.

For the quantification of $\mathrm{As}^{\mathrm{III}}$, plots of selective ion monitoring at $\mathrm{m} / \mathrm{z} 367$ were taken for $\mathrm{As}^{\mathrm{III}}$ in water (a) and urine (b) (Figure 2); 1 pg As ${ }^{\mathrm{III}}$ could be quantified.

\subsection{Precision and accuracy}

Calibration standard solutions of As were prepared by spiking stock solutions at concentrations of $0,1,10$ and $100 \mu \mathrm{gL}^{-1}$ to water and urine. The concentrations of As ${ }^{\mathrm{III}}$ determined from the peak area (y) were linear to the concentrations spiked (x) up to $100 \mu \mathrm{gL}^{-1}$, i.e., $\mathrm{y}=0.9996 \mathrm{x}+0.9763$ with a correlation coefficient of 0.9998 in water, and $y=1.000 x+0.9376$, with a correlation coefficient of 0.9996 in urine, respectively. Precision and accuracy were assessed by analysis of water and urine spiked at 1,10 and $100 \mu \mathrm{gL}^{-1}$. These samples were analyzed thrice daily as well as 
on three different days. The coefficient of variation was $<10.5 \%$, and accuracy was $88-125 \%$ for intra-day and inter-day variations in any samples (even urine spiked at 1 $\left.\mu g L^{-1}\right)$.

The blanks (e.g., water and urine that were not spiked with As) were measured six times and their standard deviations $(\sigma)$ calculated in pg based on the calibration.

LOD was defined as $3 \sigma$ for blank signals [1], so LODs were calculated to be $0.22 \mu \mathrm{gL}^{-1}$ in water, and $0.25 \mu \mathrm{gL}^{-1}$ in urine, respectively.

To check the recovery and validate the proposed procedure, standard reference materials, 2670a high-level urine and 1643e water, were examined. The high-level urine was diluted to one tenth, and the $1643 \mathrm{e}$ water was $\mathrm{pH}$ adjusted and diluted to

one-tenth, respectively, to suit assay conditions. The concentrations of $\mathrm{As}^{\mathrm{III}}$ and $\mathrm{As}{ }^{\mathrm{V}}$ in high-level urine were reported to be $59.7 \pm 2.1$ and $153 \pm 3$ [7], and $50.8 \pm 2.7$ and $166.3 \pm 6.4[8]$; our values were $53.5 \pm 4.8$ and $156.9 \pm 12.8$, respectively $(n=6)$. The concentration of total As in $1643 \mathrm{e}$ water in the NIST list was $60.45 \pm 0.72$; our value was $60.7 \pm 5.5(n=6)$.

\subsection{Comparison with other MS methods}

Solvent extraction after chelate complex formation is an effective way to concentrate transition metals from aqueous solution. We confirmed that the peak area of $\mathrm{As}(\mathrm{PDC})_{2}{ }^{+}$increased linearly up to five times without increasing the peak area of blank solution in accordance with the decrease of relative volume of MIBK from 1 to 0.2 , although enhancement factors up to 100 were reported in another study [17]. The present solvent extraction eliminates not only organic As compounds such as AsB and 
MMA that interfere with the detection of As on ICP-MS, but also matrix effects due to water-soluble ions such as $\mathrm{Na}^{+}, \mathrm{Mg}^{2+}, \mathrm{Ca}^{2+}, \mathrm{K}^{+}, \mathrm{Cl}^{-}, \mathrm{NO}_{3}{ }^{-}, \mathrm{SO}_{4}{ }^{2-}$, amino acids and proteins $[1,10,11]$. Although a solvent extraction is a simple way to eliminate interfering substances as well as matrix effects that reduce sensitivity in any kind of MS, it cannot be applicable to ICP-MS determination of several elements such as As and Cr because the carbon atom derived from organic solvents interferes with their detection especially [9]. LC separation was applied mostly for crude materials before the determination of arsenic compounds on ICP-MS and ESI-MS (/MS) $[1,6-8,10,13,15]$. Present method does not need to use LC separation for urine sample and can quantify inorganic $\mathrm{As}^{\mathrm{III}}$ and $\mathrm{As}^{\mathrm{V}}$ with the same highest sensitively as that on ICP-MS [1].

\section{References}

[1] B.K. Mandal, Y. Ogra, K.T. Suzuki, Chem. Res. Toxicol. 14 (2001) 371.

[2] S. Lalwani, T.D. Dogra, D.N. Bhardwaj, R.K. Sharma, O.P. Murty, Indian J. Clin. Biochem. 21 (2006) 70.

[3] E.H. Daughtrey Jr., A.W. Fitchett, P. Mushak, Anal. Chim. Acta 79 (1975) 199.

[4] X.C. Le, X. Lu, M. Ma, W.R. Cullen, H.V. Aposhian, B. Zheng, Anal. Chem. 72 (2000) 5172.

[5] V. Oliveila, A.M. Samiento, J.L. Gómez-Ariza, J.M. Nieto, D. Sánchez-Rodas, Talanta 69 (2006) 1182.

[6] Y. Inoue, Y. Date, T. Sakai, N. Shimizu, K. Yoshida, H. Chen, K. Kuroda, G. Endo, Appl. Organometal. Chem. 13 (1999) 81.

[7] J.J. Sloth, E.H. Larsen, K. Julshamn, J. Anal. At. Spectrom. 19 (2004), 973.

[8] R Xie, W. Johnson S. Spayd, G.S. Hall, B. Buckley, Anal. Chim. Acta 578 (2006) 
186.

[9] M. Pettine, B. Casentini, D. Mastroianni, S. Capri, Anal. Chim. Acta 599 (2007)

191.

[10] J.H. Huang G. Ilgen, B. Decker, Anal. Chim. Acta 611 (2008) 48.

[11] V. Dufailly, L. Noël, T. Guérin, Anal. Chim. Acta 611 (2008) 134.

[12] K.W.M. Siu, G.J. Gardner, S.S. Berman, Rapid Commun. Mass Spectrom. 2 (1988)

69.

[13] J.J. Corr, E.H. Larsen, J. Anal. At. Spectrom. 11 (1996) 1215.

[14] M.H. Flor ncio, M.F. Duarte, A.M.M. de Bettencourt, M.L. Gomes L.E.Vilas Boas, Rapid Commun. Mass Spectrom. 11 (1997) 469.

[15] V. Nischwitz, S.A. Pergantis, J. Agric. Food Chem. 54 (2006) 6507.

[16] C.E. Mulford, At. Absorpt. Newsl. 5 (1966) 88.

[17] K.S. Subramanian, J.C. Meranger, Anal. Chim. Acta 124 (1981) 131. 
Figure caption
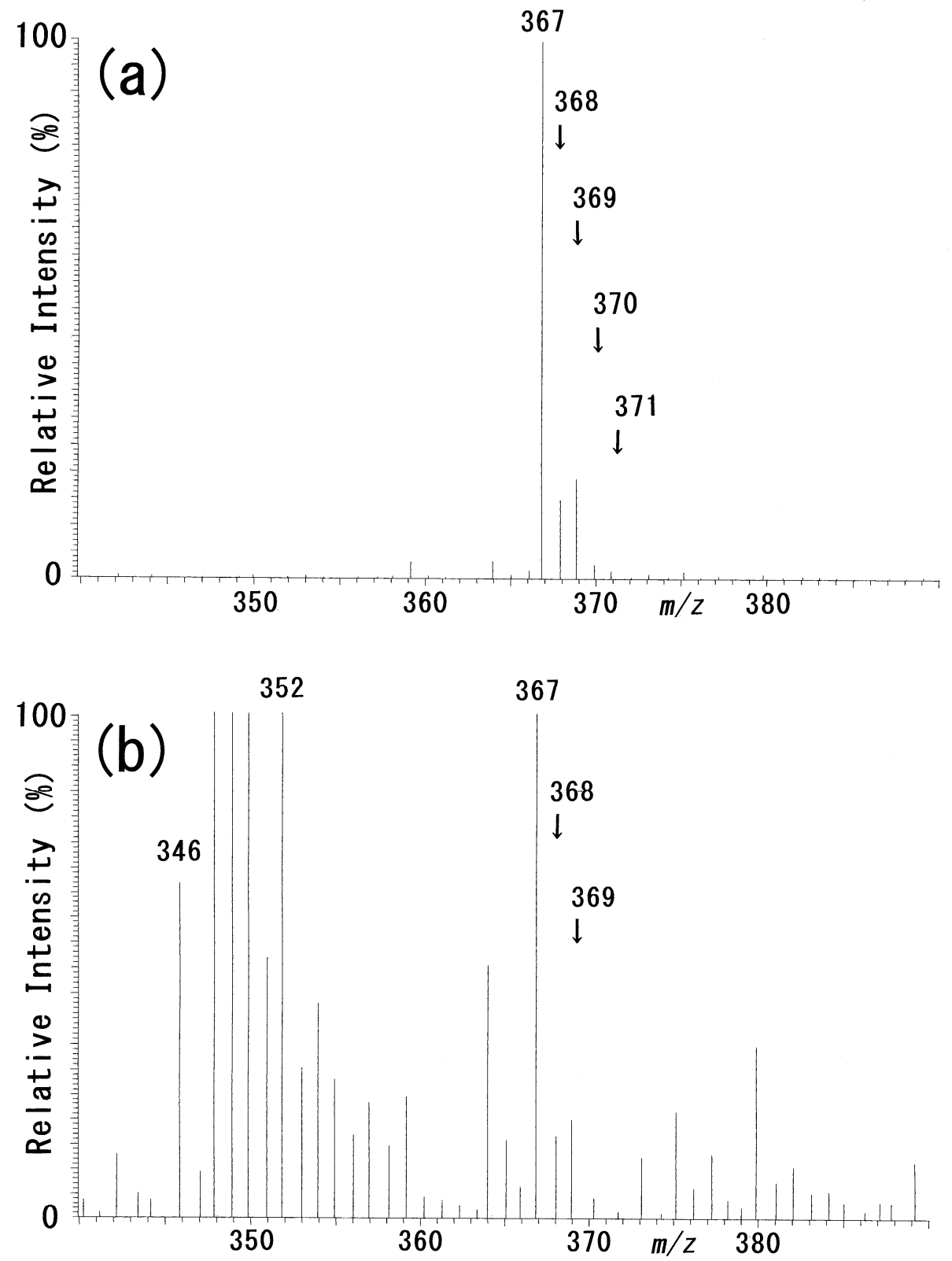

Figure 1: Mass spectrum of $\mathrm{As}(\mathrm{PDC})_{2}{ }^{+}$derived from $200 \mathrm{pg}$ of $\mathrm{As}^{\mathrm{III}}$ in water (a) and that from $10 \mathrm{pg}$ of $\mathrm{As}^{\mathrm{III}}$ in urine (b), respectively. Although As is a mono-isotopic element, the $\mathrm{As}(\mathrm{PDC})_{2}{ }^{+}$ion shows several lines due to isotopes of $\mathrm{H} \mathrm{C}, \mathrm{N}, \mathrm{O}$ and S. The theoretical abundance ratio of lines at $\mathrm{m} / \mathrm{z}$ 367: 368: 369: 340: 341 was 100.0: 15.2: 18.8: 2.6: 1.4, and the observed value in Figure 1 (b) was 100.0: 16.4: 19.8: 3.9: 0.0. 

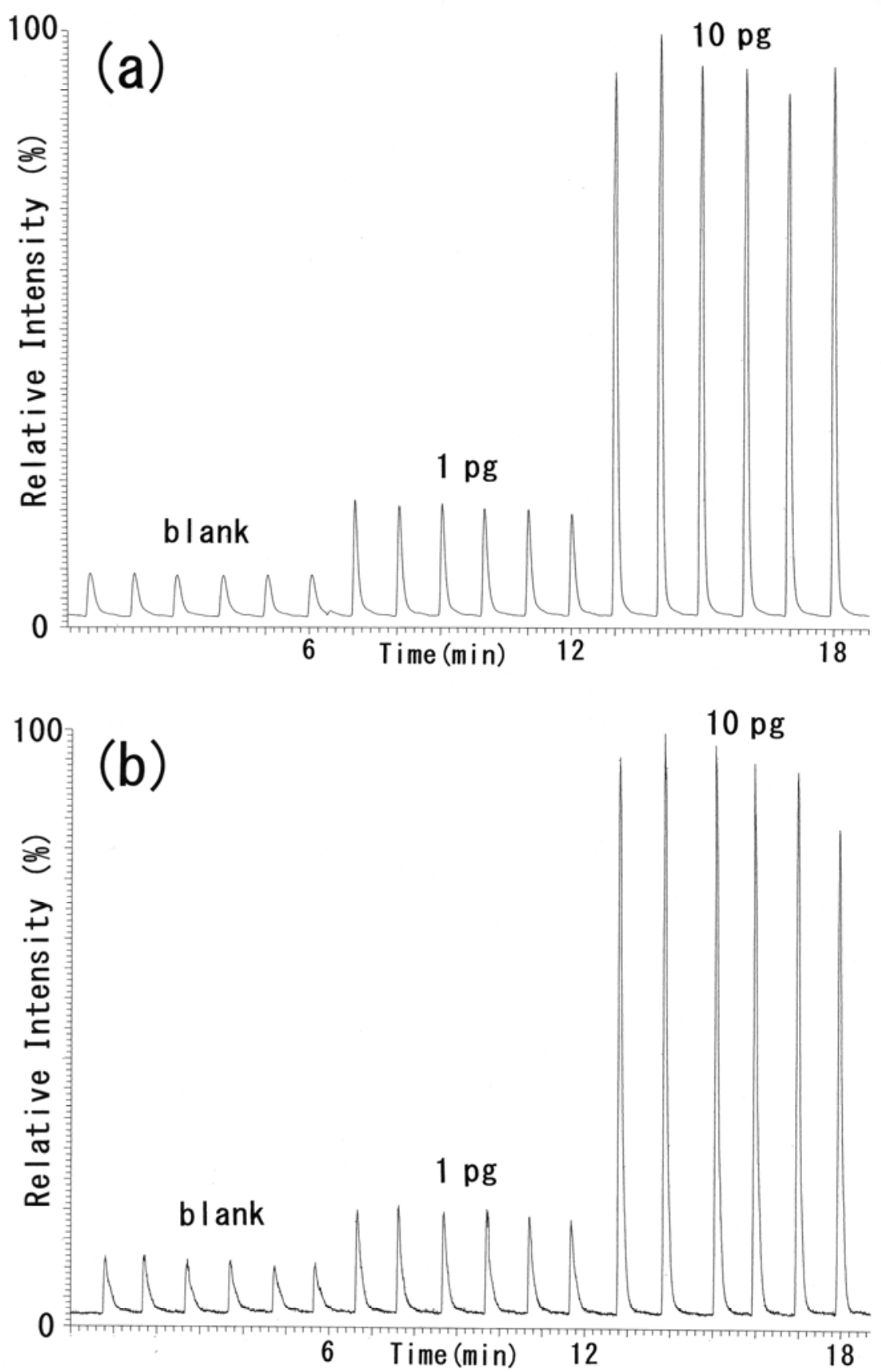

Figure 2: Plots of selected reaction monitoring at $\mathrm{m} / \mathrm{z} 367$ derived from water (a) and urine (b), respectively. Samples were injected six times for each amount of $\mathrm{As}^{\mathrm{III}}$. 